\title{
Nietzsche and the Eternal Return of Sacrifice
}

Dennis K. Keenan

Fairfield University, dkkeenan@fairfield.edu

Follow this and additional works at: https://digitalcommons.fairfield.edu/philosophy-facultypubs

\section{Peer Reviewed}

\section{Repository Citation}

Keenan, Dennis K., "Nietzsche and the Eternal Return of Sacrifice" (2003). Philosophy Faculty

Publications. 1.

https://digitalcommons.fairfield.edu/philosophy-facultypubs/1

\section{Published Citation}

Keenan, Dennis. "Nietzsche and the Eternal Return of Sacrifice." Research in Phenomenology 33 (2003): $167-185$.

This item has been accepted for inclusion in DigitalCommons@Fairfield by an authorized administrator of DigitalCommons@Fairfield. It is brought to you by DigitalCommons@Fairfield with permission from the rightsholder(s) and is protected by copyright and/or related rights. You are free to use this item in any way that is permitted by the copyright and related rights legislation that applies to your use. For other uses, you need to obtain permission from the rights-holder(s) directly, unless additional rights are indicated by a Creative Commons license in the record and/or on the work itself. For more information, please contact digitalcommons@fairfield.edu. 


\title{
NIETZSCHE AND THE ETERNAL RETURN OF SAGRIFICE
}

\author{
by \\ DENNIS KING KEENAN \\ Faifield University
}

\begin{abstract}
In the work of Nietzsche, sacrifice can only sacrifice itself over and over (in an eternal return of the same) because what it seeks to overcome (the nihilistic revelation of truth that sublates sacrifice's negation) makes this sacrifice of itself both necessayy and useless. The truth is eternally postponed in a necessary sacrificial gesture that can only sacrifice itself, thereby rendering itself useless. In the attempt to step beyond nihilism, that is, in the attempt to negate (or sacrifice) nihilism, one repeats the negation characteristic of nihilism. One becomes inextricably implicated in the move of nihilistic sacrifice. The sacrifice of the sacrifice characteristic of nihilim, that is, the sacrifice of sacrifice, can only take place as (perform itself as) the impossibility (or eternally postponed possibility) of its realization. One, therefore, produces or performs an interminable step/not beyond, an incessant step beyond that etcrnally returns.
\end{abstract}

Sacrifice is to be overcome. What could be more obvious to a reader of the work of Nietzsche? And yet, is it that obvious? A careful reading of the work of Nietzsche will reveal that in the attempt to step beyond sacrifice, one becomes inextricably implicated in the move of nihilistic sacrifice. Sacrifice returns ... eternally.

In Beyond Good and Evil (1886), Nietzsche traces a geneaolgy of sacrifice that anticipates the work of On the Genealogy of Morals (1887).

There is a great ladder of religious cruelty with many rungs; but three of them are the most important. At one time one sacrificed [opferte] human beings to one's god, perhaps precisely those human beings one loved best - the sacrifice of the first-born [Erstlings-Opfer] present in all prehistoric religions belongs here, as does the sacrifice [Opfer] of the Emperor Tiberius in the Mithras grotto on the isle of Capri, that most horrible of all Roman anachronisms. ( $7 G B, 72 / B G E, 63)$

This first rung of the great ladder of religious cruelty almost certainly refers, among other things, to the Akedah: the binding of Isaac. God 
says to Abraham: "Take your son, your only son Isaac, whom you love, and go to the land of Moriah, and offer him there as a burnt offering on one of the mountains that I shall show you" (Gen. 22: 2, New Revised Standard Version). Nietzsche also refers to Emperor Tiberius. In the waning years of his life, Tiberius (42 B.c.E. -37 G.E.), the second Roman emperor, built a dozen villas ringing Gapreae (now called Capri, near Naples), with prisons, underground dungeons, torture chambers, and execution places. Nietzsche continues up (down?) the ladder.

Then, in the moral epoch of mankind, one sacrificed [opferte] to one's god the strongest instincts one possessed, one's 'nature'; the joy of this festival glitters in the cruel glance of the ascetic, the inspired 'antinaturalist'. (JGB, 72/BGE, 63)

This second rung of the great ladder of religious cruelty is characterized by the "anti-naturalist" nihilism of ressentiment, the bad conscience, and the ascetic ideal. The third (and last) rung of the great ladder of religious cruelty puts one at the threshold of the death of God!'

Finally: what was left to be sacrificed [offerm]? Did one not finally have to sacrifice [opfem] everything comforting, holy, healing, all hope, all faith in a concealed harmony, in a future bliss and justice? Did one not have to sacrifice [opferm] God himself and out of cruelty against oneself worship stone, stupidity, gravity, fate, nothingness? To sacrifice [opferm] God for nothingness - this paradoxical mystery of the ultimate act of cruelty was reserved for the generation which is even now arising: we all know something of it already.-(JGB, 72/BGE, 63; see EI, 152/IE, 131)

To sacrifice God for nothingness reveals the concealed truth of sacrifice itself. To sacrifice God is to sacrifice the very reason of sacrifice, insofar as sacrifice is understood as a sacrifice to God for the redemption of $\sin$ (i.e., for the redemption of every kind of distancing relationship between God and human beings). To sacrifice God is to sacrifice (economical) sacrifice. To sacrifice God is to sacrifice the sacrifice that pays, that gives a return on one's investment of suffering. In On the Genealogy of Morals, Nietzsche reveals the previously concealed truth of sacrifice to be "a will to nothingness, an aversion to life, a rebellion against the most fundamental presuppositions of life" (GdM, 430/GoM, 163). It is revealed to be nihilistic insofar as it negates (sacrifices) this life in favor of a transcendent world that remunerates sacrifice. The genealogist reveals a nihilistic evaluation at the heart of sacrifice. I would suggest that the "paradoxical mystery" of the ultimate sacrifice outlined 
in the genealogy of sacrifice in Beyond Good and Evil-that is, the sacrifice of (economical) sacrifice-momentarily reveals the previously concealed truth of sacrifice and the sacrifice without reserve, sacrifice for no reason, sacrifice for nothingness. To be more precise, I would suggest that it momentarily reveals the concealed truth of sacrifice as sacrifice without reserve, sacrifice for no reason, sacrifice for nothingness.

\section{The Stroke of Genius on the Part of Christianity}

Nietzsche's genealogy of the Christian concepts of responsibility and justice is concerned with economics: credits, debts, speculation, and calculation. In the "Second Essay" of On the Genealogy of Morals, Nietzsche writes: "'E]verything has its price; all things can be paid for'-the oldest and naîvest moral canon of justice, the beginning of all 'goodnaturedness,' all 'fairness,' all 'good will,' all 'objectivity' on earth" (GdM, 322/GoM, 70). A few pages later, Nietzsche takes into account that which exceeds this justice, this economy of exchange: mercy. But instead of crediting this excess to pure goodness, to giving without reserve, he reveals in the self-destruction 'of justice (by means of mercy) a ruination of this pure goodness, a sacrifice of this giving without reserve. And insofar as one understands this giving without reserve as a sacrifice, one could say that Nietzsche reveals a sacrifice of the sacrifice of giving without reserve. He reveals a sacrifice of sacrifice.

The justice which began with, "everything is dischargeable, everything must be discharged," ends by winking and letting those incapable of discharging their debt go free: it ends, as does every good thing on earth, by overcoming itself [sich selbst aufhebend]. This self-overcoming of justice [Diese, Selbstaufhebung der Gerechtigkeit]: one knows the beautiful name it has given itself-mercy [Gnade]; it goes without saying that mercy remains the privilege [Vorrecht] of the most powerful man, or better, his-beyond the law [sein Jenseits des Rechts]. (GdM, 325/GoM, 72-73)

According to Derrida in The Gift of Death (1992), Christian justice denies itself (i.e., it overcomes itself in becoming mercy, giving without reserve) and so conserves itself in what seems to exceed it (i.e., mercy). Justice remains what it (supposedly) ceases to be: a cruel economy of debts and credits involving sacrifice $(D M, 105-6 / G D, 113-14)$. In its selfovercoming (i.e., in its becoming mercy), justice remains a privilege. It remains the "beyond the law" or super-law of the powerful person.

This same sacrifice of sacrifice is, according to Nietzsche, taken to an extreme point in the sacrifice of Christ, the creditor, for the debtor. 
[S]uddenly we stand before the paradoxical and horrifying expedient that afforded temporary relief for tormented humanity, that stroke of genius on the part of Christianity [jenem Geniestreich des Christentums]: God himself sacrifices [opfermd] himself for the guilt of mankind, God himself makes payment to himself, God as the only being who can redeem man from what has become unredeemable [unablösbar] for man himself-the creditor [der Gläubiger] sacrifices [opfernd] himself for his debtor [seinen Schuldner], out of love (can one credit that [sollte man's glauben]?), out of love for his debtor!- (GdM, 347/GoM, 92; concerning another perspective on these passages from Nietzsche's On the Genealogy of Morals, Derrida refers the reader to $C P, 282 / P C, 263-65)$.

One way to read Derrida's reading of this passage is the following: Derrida suggests that the attribution of the "stroke of genius", to Christianity is based on a thaumaturgical or miraculous secret, like "a ruse that depends on a special knowhow" (DM, 106/GD, 115). What is this miraculous secret? I would suggest (in a merely provisional way that will call for further explanation) that it is the aporia of the irreducible experience of the belief of the believer suspended between knowing (that one is redeemed) and not knowing (for certain that one is redeemed). Derrida continues: If (on the basis of this miraculous secret) one were able to attribute the "stroke of genius" to Christianity, then one would have to envelop another secret within it. This other secret confers on the name "God" the responsibility for what remains more secret than ever. This other secret is God's knowing/not knowing, which is responsible for what remains more secret than ever: the believer's special knowhow, the believer's knowing/not knowing. God's knowing/ not knowing is responsible' for the believer's knowing/not knowing, which is the (unshareable) secret shared by the Christian community through time and space. "To share a secret is not to know or to reveal the secret, it is to share we know not what: nothing that can be determined" ( $D M, 78 / G D, 80)$. What is this other secret? What is God's knowing/not knowing that is responsible for the miraculous secret of the believer's special knowhow, the believer's knowing/not knowing?

The Christian believer is redeemed only if God knows that God sacrificed, insofar as it is necessary for there to be a witness to the sacrifice in order for the sacrifice to be credited to 'Ghristianity's otherwise unredeemable account. But if God knows, then the sacrifice without reserve necessary to redeem what has become unredeemable is ruined or sacrificed. In order for God to redeem what has become unredeemable, it is necessary that God's sacrifice be a sacrifice without 
reserve, which requires that God must sacrifice zithout knowing that he sacrificed. The other secret (mentioned earlier) is God's knowing (that God sacrificed), while (at the same time) not knowing (that God sacrificed). Paradoxically, for the "stroke of genius" to "work" it is necessary (yet impossible) that God both know and not know (at the same time).

Paradoxically, Christianity has to believe that God sacrificed without God's knowing (in order for the sacrifice to be a sacrifice without reserve, a sacrifice capable of redeeming what has become unredeemable), while knowing (in order for there to be a witness to the sacrifice, in order for the sacrifice to be credited to Christianity's otherwise unredeemable account). If God knowes, then the sacrifice without reserve is sacrificed (and the belief of the debtor is empty), and if God does not know, then the debtor's account cannot be credited (and the belief of the debtor is empty). The belief of the debtor is not empty only when it is suspended (like God) between knowing and not knowing. Believing is being suspended (as God is suspended) between knowing and not knowing. Here one sees that God's knowing/not knowing is responsible for the believer's knowing/not knowing. God's knowing/not knowing is responsible for the aporia of the irreducible experience of the belief of the believer suspended between knowing (that one is redeemed) and not knowing (for certain that one is redeemed).

The irreducible experience of belief is an aporia, it is "that which remains more secret than ever" (DM,'106/GD, 115). Here there is the necessity, yet impossibility, of knowing and not knowing being at the same time. The "not yet" characteristic of the aporia interrupts the presentation of the identity (the "at the same time") of contradictories insofar as it is discovered that the moments of the aporia are not "at the same time," they can not be presented as a contradiction. The "not yet" of the aporia interrupts the "at the same time" of contradictories (see $A E, 9 / O B, 7$, and $E L, 22-23 / S L, 30-31$ ). Believing is the name for the necessity (yet impossibility) of the contradictories of believing (knowing and not knowing) being "at the same time."

The irreducible experience of belief is the believing-the knowing/ not knowing-suspended between the credit of the creditor and the credence (or faith) of the believer (or debtor). The believing is suspended between credit and faith insofar as there is a "disconnect" between what is usually thought of as an assured connection between credit and faith. Rather than being assured of redemption, believing is suspended, insofar as it is discovered that both the credit of the creditor and the faith of the believer unwork themselves. 
Paradoxically, for the "stroke of genius" to work, it has to unwork itself, that is, God can only credit the account of the debtor by sacrificing without knowing (which makes the crediting impossible) and the believer can only have faith without knowing (which makes confidence in an assured redemption impossible). The believer's faith in redemption is not empty only if, at the same time, the believer cannot count on redemption. Believing is suspended in the "not yet" of credit and the "not yet" of faith.

The irreducible experience of belief is, I would suggest, the aporia of the believing suspended between the sacrifice of the (economical) sacrifice-which requires not knowing -and the sacrifice of the sacrifice (without reserve)-which comes with knowing.

In the wake of his consideration of the irreducible experience of the aporia of belief, Derrida writes:

How can one believe this history of credence or credie? That is what Nietzsche asks, in fine, what he asks himself or has asked by another, by the specter of his discourse. Is this a false or counterfeit question, a rhetorical question as one says in English? For what makes a rhetorical question possible can sometimes disturb the structure of it.

As often happens, the call of or for the question, and the request that echoes through it, takes us further than the response. The question, the request, and the appeal must indeed have begun, since the eve of their awakening, by receiving accreditation from the other: by being believed. Nietzsche must indeed believe he knows what believing means, unless he means it is all make-believe [à moins qu'il n'entende le faire accroire]. (DM, $107 / G D, 115)$

Nietzsche asks: "Can one credit that?" or (according to Derrida's paraphrase) "How can one believe this history of credence or credit?" The question must have begun by already being believed. Said otherwise, the question Nietzsche asks implies a (negative) judgment with respect to belief (i.e., he means it is all make-believe) and at the same time presupposes (Derrida suggests) that Nietzsche already believes he knows 'what believing means. Nietzsche's believing is suspended between believing it is all make-believe (i.e., not knowing what believing means) and believing he knows what believing means. As such, Nietzsche's believing is no different from the ("true") Christian believer's believing. They are both aporetic. In both cases, the irreducible experience of belief is the irreducible experience of knowing and not knowing. 


\section{Blanchot and le pas au-delà (the step/not beyond) Nihilism}

This step beyond (economical) sacrifice that is not beyond (economical) sacrifice is also inscribed in the final pages of the "Third Essay" of Nietzsche's On the Genealogy' of Morals. At a certain moment in history, Nietzsche writes in On the Genealogy of Morals, the will to truth is revealed in its truth. When Christian truthfulness asks itself "What is the meaning of all will to truth?" it will bring about its own destruction through an act of self-overcoming. In the "Second Essay," Nietzsche writes that justice "ends, as does every good thing on earth, by overcoming itself [sich selbst aufhebend]" (GdM, 325/GoM, 73). Echoing this earlier consideration of the self-overcoming of justice (Diese Selbstaufhebung der Gerechtigkeit), Nietzsche writes: "All great things bring about their own destruction through an act of self-overcoming [Selbstaufhebung]: thus the law of life will have it, the law of the necessity of 'self-overcoming' [Selbstüberwindung] in the nature of life - the lawgiver himself eventually receives the call: 'patere legem, quam ipse tulisti' ['submit to the law you yourself proposed']" (GdM, 428/GoM, 161). This necessary act of self-overcoming, this Aufhebung that is at the threshold of a step beyond nihilism is "weakened" by the very work of On the Genealogy of Morals. In response to the question "What is the meaning of all will to truth?", the final dramatically climactic lines of the work answer: "[W]hat is expressed by all that willing which has taken its direction from the ascetic ideal" is " $a$ will to nothingness, an aversion to life, a rebellion against the most fundamental presuppositions of life; but it is and remains a will!... And, to repeat in conclusion what I said at the "beginning: man would rather will nothingness than not will". (GdM, $430 /$ GoM, 162-63). The willing that has taken its direction from the sacrifice, the saying "No" characteristic of the ascetic ideal, is revealed as a will to nothingness. It is revealed as nihilistic. Here is a moment in history when history is revealed in its truth. Here is a momentary revelation of the previously concealed truth of sacrifice and the sacrifice without reserve, sacrifice for no reason, sacrifice for nothingness. To be more precise, I would suggest that it is the momentary revelation of the concealed truth of sacrifice as sacrifice without reserve, sacrifice for no reason, sacrifice for nothingness. Here is also the prophesying of the extreme form of nihilism: the overman as the one who maintains this pure essence of will in willing nothingness. The overman reveals the truth of (economical) sacrifice and sacrifices (economical) sacrifice. The overman reveals the truth of (economical) sacrifice as the 
sacrifice of (economical) sacrifice. But this Aufhebung that is a step beyond nihilism insofar as it reveals a concealed evaluation as the truth of history, repeats the evaluative move characteristic of nihilism thereby reinscribing the step beyond nihilism into the not beyond. The genealogist becomes inextricably implicated in the nihilistic sacrifice of the ascetic priest. The genealogist's sacrifice of the sacrifice characteristic of nihilism, that is, the genealogist's sacrifice of sacrifice, can only take place as the impossibility (or eternally postponed possibility) of its realization. The genealogist, therefore, produces or performs an interminable step/not beyond (le pas au-delà), a step beyond that eternally returns.

Although the eternal return remains merely implicit in the structure of On the Genealogy of Morals, Nietzsche explicitly draws a connection between the eternal return and nihilism in one of the notes of what was to be The Will to Power: Attempt at a Revaluation of All Values-a text that Nietzsche refers to as a "work in progress" (GdM, 427/GoM, 160) in the final pages of On the Genealogy of Morals.

Let us think this thought in its most terrible form: existence as it is, without meaning or aim, yet recurring inevitably without any finale of nothingness: "the etemal recurrence."

This is the most extreme form of nihilism: the nothing (the "meaningless"), eternally! (NF, 217/WP, 35-36)

This passage 'tells one that the extreme form of nihilism is precisely where the possibility of coming to an end-that is, the possibility of maintaining the pure essence of will in willing nothingness-turns into the impossibility 'of coming to an end. In The Infinite Conversation (1969), Blanchot writes:

Until now we thought nihilism was tied to nothingness. How ill-considered this was: nihilism is tied to being. Nihilism is the impossibility of being done with' it and of finding a way out even in that end that is nothingness. It says the impotence of nothingness, the false brilliance of its victories; it tells us that when we think nothingness we are still thinking being. Nothing ends, everything begins again; the other is still the same. Midnight is only a dissimulated noon, and the great Noon is the abyss of light from which we can never depart. (EI, 224/IC, 149)

This weakening of negation-which is also experienced at those decisive moments in the Phenomenology of Spirit (1807), in history, when negation is discovered to be at a certain distance from the Phenomenology, of Spirit, from history-will have profound consequences. 
[I]f we will grant that all modern humanism, the work of science, and planetary development have as their object a dissatisfaction with what is, and thus the desire to transform being-to negate it in order to derive power from it and to make of this power to negate the infinite movement of human mastery-then it will become apparent that this sort of weakness of the negative, and the way in which nothingness unmasks itself in the being that cannot be negated, lays waste at one stroke to our attempts to dominate the earth and to free ourselves from nature by giving it a meaning - that is, by denaturing it. (EI, 225/IC, 149)

The desire to transform being by negating it, fueled by a dissatisfaction with what is, is interrupted by the weakness of the negative. Nihilism is the impossibility of being done with the being with which one is dissatisfied and of finding a way out even in that end that is nothingness. One can never definitively go beyond.

This production of a step/not beyond is likewise traced in Thus Spoke Zarathustra (1883-1885). Zarathustra prophesies the overman as the overcoming of the nihilistic evaluations of human beings. The overman, insofar as he maintains the pure essence of will in willing nothingness, is the pure form of nihilism. Blanchot writes:

[H]is [i.e., the overman's] essential trait, the will, would make him, in his pure rigor and his harshness, the very form of nihilisim for, according to Nietzsche's clear statement, "the will would rather will nothingness than not will" [GdM, 430/GoM, 163]. The overman is he in whom nothingness makes itself will and who, free for death, maintains this pure essence of will in willing nothingness. This would be nihilism itself. (EI, 222/ $I C, 148$ )

At this moment, the overman, like Dasein in the act of authentic (eigentlich), resolute, determinate, and decided assumption of death, is "free for death" (see $S Z, 266 / B T, 311$ ). This would be the extreme point or extreme form of nihilism. But in Thus Spoke Zarathustra, as in On the Genealogy of Morals, this step beyond is equivocal. Immediately following his announcement of the eternal return in "On the Vision and the Riddle," Zarathustra encounters a young shepherd gagging on a heavy black snake. In "The Convalescent," Zarathustra's remarks are reminiscent of this encounter: "The great disgust with man-this choked me and had crawled into my throat; and what the soothsayer said: 'All is the same, nothing is worth while, knowledge chokes.' A long twilight limped before me, a sadness, weary to death, drunken with death [eine todesmiude, todestrunkene Traurigkeit], speaking with a yawning 
mouth. 'Eternally recurs the man of whom you are weary, the small man'" (ASZ, 270/TSZ, 219). Zarathustra's disgust arises, Blanchot writes, from his understanding that

he will never definitively go beyond man's insufficiency, or that he will only be able to do so, paradoxically, by willing his return [retour]. But what does this return [retour] mean? It means what it affirms: that the extreme point of nihilism is precisely there' where it reverses itself [se renverse], that nihilism is this very turning itself [le reloumement même], the affirmation that, in passing from the No to the Yes, refutes nihilism, but does nothing other than affirm it, and henceforth extends it to every possible affirmation [a footnote here reads: "Hence one can conclude that nihilism identifies itself with the will to surmount it absolutely" (EI, 225 n. $1 / I C, 451$ n. 9).] $(E I, 225 / I C, 149-50)$

In the attempt to step beyond nihilism, that is, in the attempt to negate (or sacrifice) nihilism, one repeats the negation characteristic of nihilism. One becomes inextricably implicated in the move of nihilistic sacrifice. The sacrifice of the sacrifice characteristic of nihilism, that is, the sacrifice of sacrifice, can only take place as the impossibility (or eternally postponed possibility) of its realization. One, therefore, produces or performs an interminable step/not beyond, an incessant step beyond that eternally returns.

\section{Ressentiment and the Action Characteristic of Jesus' Evangelic Practice}

An irreducibly paradoxical genealogy, similar to the one traced in $O n$ the Genealogy of Morals, is traced by Nietzsche in The Anti-Christ (1895). Nietzsche begins his genealogy with a people whose national selfconfidence (DA, 191-92/TA, 135-36) is so great that it needs a god to whom it can express its gratitude in the form of sacrifice.

A people which still believes in itself still also has its own God. In him it venerates the conditions through which it has prospered, its virtues'it projects' its joy in itself, its feeling of power on to a being whom one 'can thank for them. He who is rich wants to' bestow; a proud people needs a God in order to sacrifice [opfern].... Within the bounds of such presuppositions religion is a form of gratitude. One is grateful for oneself: for that one needs a God.- Such a God must be able to be both useful and harmful, both friend and foe-he is admired in good and bad alike. The anti-natural castration of a God into a God of the merely good would be totally undesirable here. $(D A, 180 / T A, 126)$ 
"God" here is merely the name of the projection of a people's own affirmation of itself onto a being to whom it can thank for the conditions through which it prospered. This "God" is fundamentally "a word [Wort] for every happy inspiration of courage and self-reliance" $(D A, 192 / I A, 136)$. This "God" is a God before whom one affirms this world, rather than denies this world. It is a God before whom sacrifice is a form of gratitude, rather than a means of redemption.

The good conscience of this national self-affirmation resembles the noble morality considered in the "First Essay" of Nietzsche's On the Genealogy of Morals. Noble morality "develops from a triumphant affirmation of itself." Noble morality "acts and grows spontaneously" ( $G d M, 284-85 / G o M, 36-37$ ), while the action of slave morality is fundamentally reaction against the noble. With the Jews there begins the slave revolt in morality, which involves a radical revaluation or inversion of their enemies' values, that is, a reaction or imaginary -revenge against the noble mode of valuation (GdM, 281-82/GoM, 33-34).

In my Genealogy of Morals I introduced for the first time the psychology of the antithetical concepts of a noble morality and a ressentiment morality, the latter deriving from a denial [aus dem Nein] of the former: but this latter corresponds totally to Judeo-Christian morality. To be able to reject all that represents the ascending movement of life, well-constitutedness, power, beauty, self-affirmation on earth, the instinct of ressentiment here become genius had to invent another world from which that lifeaffirmation would appear evil, reprehensible as such. (DA, 190/TA, 135)

In both Judaism and Christianity (albeit in different forms), the instinct of ressentiment is predicated on denial or sacrifice. Ressentiment is a denial or sacrifice of this world, with the simultaneous invention of another world "beyond" this world. The chasm between these two worlds opened up by this denial or sacrifice is accompanied by a feeling of guilty indebtedness from which one attempts to redeem oneself through sacrifices. These sacrifices were progressively interiorized until they took on the form of the asceticism of self-sacrifice. "[A]n ascetic life is a self-contradiction: here rules a ressentiment without equal, that of an insatiable instinct and power-will that wants to become master not over something in life, but over life itself, over its most profound, powerful, and basic conditions; here an attempt is made to employ force to block up the wells of force; here physiological well-being itself is viewed askance, and especially the outward expression of this well-being, beauty and joy; while pleasure is felt and sought in ill-constitutedness, 
decay, pain, mischance, ugliness, voluntary deprivation, self-mortification, self-flagellation, self-sacrifice [Selbstopferung]" (GdM, 381/GoM, 117-18). This progressive interiorization of sacrifice culminating in ascetic selfsacrifice testifies to the progressive abstraction from natural life.

Jewish morality, which does not venerate the conditions through which a nation has prospered, is not an affirmation of life, but rather has "become abstract [abstrakt], become the antithesis of life" (DA, 192/TA, 136). Christian morality invents "an even more abstract [einer noch abgezogneren] form of existence" than the one conditioned by the social hierarchy of Jewish ecclesiastical teaching $(D A, 195 / T A, 139)$. A people characterized by national self-confidence i "perishes if it mistakes its own duty for the concept of duty in general. Nothing works more profound ruin than any 'impersonal' duty, any sacrifice [Opferung] to the Moloch of abstraction [Abstraktion]. -Kant's categorical imperative should have been felt as mortally dangerous! ..." $(D A, 175 / T A, 122)$. Access to acting from duty (i.e., from respect for the law, as opposed to according to duty) involves, according to Kant, a sacrifice of the "pathological" interests. The unconditionality of respect for the law involves a sacrifice of everything that links one's sensibility to calculation, that is, to the conditionality of hypothetical imperatives. "If a rational creature could ever reach the stage of thoroughly liking to do all moral laws, it would mean that there was no possibility of there being in him a desire which could tempt him to deviate from them, for overcoming such a desire always costs the subject some sacrifice [Aufopferung] and requires self-compulsion [Selbstzwang], i.e., an inner constraint to do that which one does not quite like to do" (KPV, 83-84/CPR, 86). In The Gift of Death, Derrida echoes certain Nietzschean concerns regarding this sacrifice that requires self-compulsion, when he points out that Kant closely links sacrifice to debt and duty, which are never separable from the guilt (Schuldigkeit) from which one can never be acquitted $(D M, 88-89 / G D, 92-93)$. This unredeemable situation described by Kant found its genesis, according to Nietzsche, in the "stroke of genius" on the part of Christianity. Though the sacrifice of the Christian God afforded temporary relief for tormented humanity from what had become unredeemable, it is merely that: temporary. Christ's sacrifice merely replaces one unredeemable debt with another unredeemable debt.

The advent of the Christian God was accompanied by the greatest feeling of guilty indebtedness $(G d M, 346 / G 0 M, 90)$, which in turn called 
for the greatest degree of the redemptive asceticism of self-sacrifice. "The Christian faith is from the beginning sacrifice [Opferung]: sacrifice [Opferung] of all freedom, all pride, all self-confidence of the spirit, at

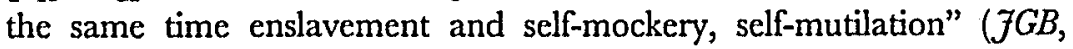
64/BGE, 57). In On the Genealogy of Morals, Nietzsche suggests that Jesus of Nazareth was this seduction of ressentiment in "its most uncanny and irresistible form" (GdM, 282/GoM, 35). But in The Anti-Christ, the genealogy has changed. While Nietzsche still maintains that Jewish morality and Christian morality are moralities of ressentiment, he writes that Jesus is a "free spirit" ( $D A, 202 / T A, 144)$ who is characterized by "the freedom from, the superiority over every feeling of ressentiment" (DA, 211/TA, 153). The "glad tidings" of Jesus are, according to Nietzsche, an interruption of the Judeo-Christian morality of ressentiment. This momentary interruption was preceded by the Jewish form of ressentiment and was followed by the Ghristian form of ressentiment.

This interruption (by the "glad tidings" of Jesus) was preceded by Jewish ecclesiastical teaching. The Jews, in revenge on their enemies, had "separated their God from themselves and raised him on high" $(D A, 212 / T A, 153)$. There now exists a will of God as to what human beings are to do and not to do. With the introduction of this lie of a "moral world-order," the concept of God is falsified. The ruling power of the will of God is now expressed as punishment and reward commensurate with one's degree of obedience to that will. The priest exists as the perpetrator of this lie.

For one must grasp this: every natural custom, every natural institution (state, administration of justice, marriage, tending of the sick and poor), every requirement presented by the instinct for life, in short everything valuable in itself, becomes utterly valueless, inimical to value through the parasitism of the priest (or the 'moral world-order'): a sanction is subsequently required-a value-bestowing power is needed which denies [verneint] the natural quality in these things and only by doing so is able to create a value.... The priest disvalues, dissanctifies nature: it is only at the price of this that he exists at all.-Disobedience of God, that is to say of the priest, of 'the Law', now acquires the name 'sin'. (DA, 194-95/TA, 138)

The priest creates value only through the denial of the natural quality of things. With the Jews, a priestly people embodying the most deeply repressed priestly vengefulness, there begins the slave revolt in morality (GdM, 281-82/GoM, 34). This revolt begins when "ressentiment itself becomes creative and gives birth to values: the ressentiment of 
natures that are denied [versagt] the true reaction, that of deeds, and compensate themselves with an imaginary revenge" ( $G d M, 284 / G o M$, 36). Ressentiment is predicated on denial or sacrifice. Ressentiment is a denial or sacrifice of natural life, with the simultaneous invention of a supernatural life. The chasm between these two types of life opened up by this denial or sacrifice is (especially with the advent of the Christian God) accompanied by a feeling of guilty indebtedness from which one attempts to redeem oneself through sacrifices. One sought redemption from any kind of distancing relationship with God, that is, from "sin," the priestly name for the bad conscience or feeling of guilty indebtedness $(D A, 203 / T A, 145, G d M, 407 / G o M, 140)$, through sacrifices. The priest is everywhere indispensable for the redemption of "sin" through sacrifice.

If ressentiment is predicated on denial or sacrifice, then the action characteristic of Jesus' evangelic practice is a denial of this denial, a sacrifice of this sacrifice.

In the entire psychology of the 'Gospel' the concept guilt and punishment is lacking; likewise the concept reward. 'Sin', every kind of distancing relationship between God and man, is abolished - precisely this is the 'glad tidings'. Blessedness is not promised, it is not tied to any conditions: it is the only reality. $(D A, 203 / T A, 145)$

The consequence of this reality is lived as a new practice. Jesus is distinguished not by belief, but by a different mode of acting. Nietzsche lists Jesus' true evangelic practices: he does not resist (either by words or in his heart), he makes no distinction between native and foreigner, or between Jew and non-Jew, he is not angry with anyone, he does not disdain anyone, and "he entreats, he suffers, he loves with those, in those who are doing evil to him" (DA, 203, 205/TA, 145-46, 148). The life of Jesus was a denial of Jewish ecclesiastical teaching.

The life of the redeemer was nothing else than this practice - his death too was nothing else.... He no longer required any formulas, any rites for communicating with God-not even prayer. He has settled his accounts with the whole Jewish penance-and-reconciliation doctrine; he knows that it is through the practice of one's life that one feels 'divine', 'blessed', 'evangelic', at all times a 'child of God'. It is not 'penance', not 'prayer for forgiveness' which leads to God: evangelic practice alone leads to God, it is God!-What was abolished with the Evangel was the Judaism of the concepts 'sin', 'forgiveness of sin', 'faith', 'redemption by faith'-the whole of Jewish ecclesiastical teaching was denied [verneint] in the 'glad tidings'. $(D A, 203-4 / T A, 146)$ 
Jesus denied (geleugnet) any chasm between God and human beings ( $D A$, $213 / T A, 154)$. As a consequence of this denial, the whole of Jewish ecclesiastical teaching was denied (verneint). He denied an economic conception of sacrifice, that is, any sacrifice performed in the name of bridging any distancing relationship between God and human beings. Jesus likewise denied the denial of the world that sets up a chasm between God and human beings. Jesus "never had any reason to deny [verneinen] 'the world', he had no notion of the ecclesiastical concept 'world'.... Denial [Das Verneinen] is precisely what is totally impossible for him" (DA, 202/TA, 145). Jesus denied the denial characteristic of nihilism. He denied the nihilistic sacrifice that produces this chasm, as well as the sacrifices performed in the name of bridging this chasm. Jesus denied denial; he sacrificed sacrifice. This sacrifice of sacrifice steps beyond sacrifice, at the same time as it repeats what it steps beyond. Jesus' action is (in Blanchot's words) the step/not beyond (le pas au-delà) sacrifice.

Jesus' action suspends him, if only for a moment, between the apparent world and the "real" world. Jesus" "world" is not beyond the apparent world (as is the case with St. Paul, according to Nietzsche). But Jesus' "world" is likewise, according to the "logic" of "How the "Real World' at last Became a Myth," not the apparent world, for the apparent world only makes sense in relation to a real world. The extreme moment of this "History of an Error" from Tivilight of the Idols, or How to Philosophize with a Hammer (1889) reads:

We have abolished the real world: what world is left? the apparent world perhaps?... But no! with the real world we have also abolished the apparent world!

(Mid-day; moment of the shortest shadow; end of the longest error; zenith of mankind; INCIPIT ZARATHUSTRA.) $(G D, 75 / 77,41)$

Jesus' world is nothing but the "not yet" characteristic of the step/not beyond the apparent world, nothing but the "not yet" of being suspended, if only for a moment, between the apparent world and the real world. Nietzsche describes this suspension in the "not yet," I would suggest, as nothing but the pure transposition characteristic of the inner world of metaphor.

The concept, the experience 'life' in the only form he knows it is opposed to any kind of word, formula, law, faith, dogma. He [i.e., Jesus] speaks only of the inmost thing: 'life' or 'truth' or 'light' is his expression for the inmost thing - everything else, the whole of reality, the whole of 
nature, language itself, possess for him merely the value of a sign, a metaphor. $(D A, 202 / T A, 144)$

If I understand anything of this great symbolist it is that he took for realities, for 'truths', only inner realities - that he understood the rest, everything pertaining to nature, time, space, history, only as signs, as occasion for metaphor. (DA, 204/TA, 146)

This inner world of metaphor is the "not yet" of any world; it is the denial of every reality. It is the denial of the denial of the apparent world, the sacrifice of the sacrifice of the apparent world.

Insofar as Jesus denies every reality, and insofar as he maintains the pure essence of will in willing nothingness, and insofar as he is the extreme form of nihilism, is Jesus an overman? Recall that for Blanchot, the overman embodies the step/not beyond (le pas au-dela) nihilism.

This interruption of Judaism by the "glad tidings" of Jesus was followed by the ressentiment of St. Paul. It was followed by the Pauline perversion of the evangelic practice. Jesus abolished every kind of distancing relationship between God and human beings and proclaimed that it is through his evangelic practice alone that one feels at all times a "child of God" (DA, 203-4/TA, 145-46).'Jesus taught the equal right of everyone to be a child of God. But this teaching fell prey to ressentiment. The enraged reverence of the "theologian" possessed by ressentiment could "no longer endure that evangelic equal right of everyone to be a child of God which Jesus had taught, and their revenge consisted in exalting Jesus in an extravagant fashion, in severing him from themselves: just as the Jews, in revenge on their enemies, had previously separated their God from themselves and raised him on high" $(D A, 212 / T A, 153)$. The one God and the one Son of God are both, according to Nietzsche, products of ressentiment. St. Paul perverted this "evangelic equal right of everyone to be a child of God [evangelische Gleichberechtigung von Jedermann zum Kind Gottes]" into "the doctrine "equal rights for all' [der Lehre 'gleiche Rechte für Alle]" (DA, 215/TA, 156) by shifting the center of gravity of life out of life into the "Beyond" and perpetuating the great lie of personal immortality, the great lie that everybody (as an immortal soul) is equal (gleichen) to everybody else (DA, 215/TA, 155-56).

St. Paul was, according to Nietzsche, an' apostle of ressentiment. 'With St. Paul, the unevangelic feeling of revengefulness again came uppermost $(D A, 212 / T A, 153)$. St. Paul embodied the anti-thetical type to the "bringer of glad tidings." He was the genius of hatred. "What did this dysangelist not sacrifice [Opfer] to his hatred!"' $(D A, 214 / T A, 154)$. 
St. Paul's supreme sacrifice was shifting the center of gravity of life out of life into the "Beyond" and perpetuating the great lie of personal immortality. If Jesus' action can be interpreted as the sacrifice of (economical) sacrifice, then St. Paul could be interpreted as sacrificing this sacrifice of (economical) sacrifice. St. Paul restored (economical) sacrifice. The unreasonable sacrifice of Jesus was replaced by the reasonable sacrifice of St. Paul. St. Paul thirsted for reasons-"reasons relieve" (GdM, 407/GoM, 140).

-And now an absurd problem came up: 'How could God have permitted that?' For this question the deranged reason of the little community found a downright terrifyingly absurd answer: God gave his Son for the forgiveness of sins, as a sacrifice [Opfer]. All at once it was all over with the Gospel! The guill sacrifice [Schuldopfer], and that in its most repulsive, barbaric form, the sacrifice [Opfer] of the innocent man for the sins of the guilty! What atrocious paganism!-For Jesus had done away with the concept 'guilt' itself- he had denied [geleugnet] any chasm between God and man, he lived this unity of God and man as his 'glad tidings'.... And not as a special prerogative!-From now on there is introduced into the type of the redeemer step by step: the doctrine of a Judgement and a Second Coming, the doctrine of his death as a sacrificial death [Opfertode], the doctrine of the Resurrection with which the entire concept "blessedness', the whole and sole reality of the Evangel, is juggled away-for the benefit of a state after death! $(D A, 212-13 / T A, 153-54)$

The ressentiment of Judaism, interrupted by the "glad tidings" of Jesus, was replaced by the ressentiment of St. Paul.

Sacrifice can only sacrifice itself over and over (in an eternal return of the same) because what it seeks to overcome (the nihilistic revelation of truth that sublates sacrifice's negation) makes this sacrifice of itself both necessary and useless. The truth is eternally postponed in a necessary sacrificial gesture that can only sacrifice itself, thereby rendering itself useless. In the attempt to step beyond nihilism, that is, in the attempt to negate (or sacrifice) nihilism, one repeats the negation characteristic of nihilism. One becomes inextricably implicated in the move of nihilistic sacrifice. The sacrifice of the sacrifice, characteristic of nihilism, that is, the sacrifice of sacrifice, can only take place as (perform itself as) the impossibility (or eternally postponed possibility) of its realization. One, therefore, produces or performs an interminable step/not beyond, an incessant step beyond that eternally returns. Sacrifice remains as a spectral presence insofar as sacrifice infinitely approaches (or withdraws from) revelation. 


\section{ABBREVIATIONS}

$A E / O B \quad$ Emmanuel Levinas. Autrement qu'être ou au-dela' de l'essence. Dordrecht: Kluwer Academic Publishers, 1991. Translated by Alphonso Lingis under the title Othereise Than Being or bgond Essence (The Hague: Martinus Nijhoff Publishers, 1981).

ASZ/TSZ Friedrich Nietzsche. Also sprach Zarathustra: Ein Buch fir Alle und Keinen. In bd. 1, abt. 6 of Werke: Kritische Gesamtausgabe. Edited by Giorgio Colli and Mazzino Montinari. Berlin: Walter de Gruyter \& Co., 1968. Translated by Walter Kaufmann under the title Thus Spoke Zarathustra: $A$ Book for All and None (Harmondsworth, Middlesex, England: Penguin Books Ltd., 1978).

CP/PC Jacques Derrida. La carte postale de Socrate à Freud et au-delà. Paris: Flammarion, 1980. Translated by Alan Bass under the title The Post Card: From Socraies to Freud and Beyond (Chicago: The University of Chicago Press, 1987).

DA/TA Friedrich Nietzsche. Der Antichrist: Fluch auf das Christenthum. In bd. 3, abt. 6, of Werke: Kritische Gesamtausgabe. Edited by Giorgio Colli and Mazzino Montinari, 163-251. Berlin: Walter de Gruyter \& Co., 1969. Translated by $\mathrm{R}$. J. Hollingdale under the title The Anti-Christ, in Twilight of the Idols and The Anti-Christ (Harmondsworth, Middlesex, England: Penguin Books Ltd., 1968), 113-87.

$D M / G D$ Jacques Derrida. Donner la mort. In L'éthique du don, Jacques Derrida et la pensée du don, 11-108. Paris: Métailié-Transition, 1992. Translated by David Wills under the title The Gifl of Death (Chicago: The University of Chicago Press, 1995).

EI/IC Maurice Blanchot. L'entretien infini. Paris: Éditions Gallimard, 1969. Translated by Susan Hanson under the title The Infinite Conversation (Minneapolis: University of Minnesota Press, 1993).

EI/IE Georges Bataille. L'experience intericure. In vol. 5 of EEuvres complètes, 7-189. Paris: Éditions Gallimard, '1973. Translated by Leslie Anne Boldt under the title Inner Experience (Albany: State University of New York Press, 1988).

EL/SL Maurice Blanchot. L'espace littéraire; Paris: Éditions Gallimard, 1955. Translated by Ann Smock under the title The Space of Literature (Lincoln: University of Nebraska Press, 1982).

GD/TI Friedrich Nietzsche. Götzen-Dämmerung, oder Wie man mil dem Hammer philosophirt. In bd. 3, abt. 6, of Werke: Kritische Gesamtausgabe. Edited by Giorgio Colli and Mazzino Montinari, 49-157. Berlin: Walter de Gruyter \& Co., 1969. Translated by R. J. Hollingdale under the title Twilight of the Idols, or How to Philosophize with a Hammer, in Twilight of the Idols and The Anti-Christ (Harmondsworth, Middlesex, England: Penguin Books Lid., 1968), 19-112:

GdM/GoM Friedrich Nietzsche. Zur Genealogie der Moral: Eine Streitschrifl. In bd. 2, abt. 6, of Werke: Kritische Gesamtausgabe. Edited by Giorgio Colli and Mazzino Montinari, 257-430. Berlin: Walter de Gruyter \& Co., 1968. Translated by Walter Kaufmann and R. J. Hollingdale under the title On the Genealogy of Morals: A Polemic, in On the Genealogy of Morals and Ecce Homo (New York: Random House, Inc., 1967), 13-163.

JGB/BGE Friedrich Nietzsche. Jenseils von Gut und Böse: Vorspiel einer Philosophie der Zukunfl. In bd. 2, abt. 6, of Werke: Kritische Gesamtausgabe. Edited by Giorgio Colli and Mazzino Montinari, 1-255. Berlin: Walter de Gruyter \& Co., 1968. Translated by R. J. Hollingdale under the title Beyond Good and Evil Prelude to a Philosophy of the Future (Harmondsworth, Middlesex, England: Penguin Books Ltd., 1972). 
KPV/CPR Immanuel Kant. Kritik der praktischen Verunfl. In vol. 5 of Kant's Gesammelte Schriften, edited by Königlich Preussischen Academie der Wissenschaften, 1-163. Berlin: Druck und Verlag von Georg Reimer, 1908. Translated by Lewis White Beck under the title Critique of Practical Reason (Indianapolis: Bobbs-Merrill Company, Inc., 1956).

NF/WP Friedrich Nietzsche. Nachgelassene Fragmente. In bd. 1, abt. 8, of Werke: Fritische Gesamtausgabe. Edited by Giorgio Colli and Mazzino Montinari. Berlin: Walter de Gruyter \& Co., 1974. Translated by Walter Kaufmann and R. J. Hollingdale under the title The Will to Power (New York: Random House, Inc., 1967).

SZ/BT Martin Heidegger. Sein und Zeit. 16th ed. Tübingen: Max Niemeyer Verlag, 1986. Translated by John Macquarrie and Edward Robinson under the title Being and Time (New York: Harper \& Row, Publishers, 1962). 


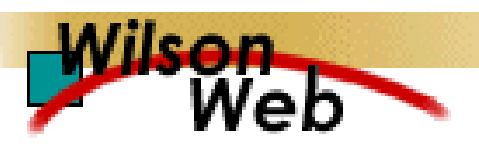

\section{COPYRIGHT INFORMATION}

TITLE: Nietzsche and the Eternal Return of Sacrifice

SOURCE: Res Phenomenol 332003

WN: 0300100948010

The magazine publisher is the copyright holder of this article and it is reproduced with permission. Further reproduction of this article in violation of the copyright is prohibited.

Copyright 1982-2003 The H.W. Wilson Company. All rights reserved. 